\title{
HUBUNGAN ANTARA NILAI KERJA, BERBAGI PENGETAHUAN, DAN KINERJA KREATIF: STUDI PADA PEKERJA KONSTRUKSI DI JAKARTA
}

\author{
Bimmo Dwi Baskoro ${ }^{1 *}$, Saipul Al Sukri², Dwi Ermayanti Susilo ${ }^{3}$ \\ ${ }^{1}$ Sekolah Tinggi Manajemen Labora, Jakarta \\ ${ }^{2}$ Fakultas Ekonomi dan IImu Sosial, UIN Sultan Syarif Kasim, Riau \\ ${ }^{3}$ Sekolah Tinggi Ilmu Ekonomi PGRI Dewantara, Jombang, Jawa Timur \\ *Alamat Email: bimmodibi@gmail.com
}

\begin{abstract}
ABSTRAK
Tujuan penelitian ini adalah untuk mengetahui pengaruh nilai-nilai kerja karyawan konstruksi terhadap kinerja kreatif dan menguji peran mediasi berbagi pengetahuan di antara variabel tersebut. Penelitian ini melibatkan 315 responden dari berbagai perusahaan konstruksi di Jakarta untuk menguji hipotesis penelitian. Berbagi pengetahuan berperan sebagai mediator antara dimensi kenyamanan dan dimensi status dari nilai-nilai kerja terhadap kinerja kreatif. Penelitian ini memberikan informasi pengaruh nilai-nilai kerja terhadap kinerja kreatif dari industri konstruksi dan mengkonfirmasi peran berbagi pengetahuan dalam memediasi dimensi nilai-nilai kerja.

Kata Kunci: nilai kerja, kinerja kreatif, berbagi pengetahuan, konstruksi, Jakarta
\end{abstract}

\begin{abstract}
This research aimed to indicate the effect of work values of construction employees towards creative performance and to assess the role of mediation about sharing the knowledge among those variables. This research involved 315 respondents from various construction companies in Jakarta for assessing hypothesis research. Knowledge sharing had the role as mediator among comfort and status dimensions from work values towards creative performance. This research provided information about effect of work values towards creative performance from construction industry and confirmed the role of knowledge sharing in mediating work values dimension.

Keywords: work values, creative performance, knowledge sharing, construction; Jakarta
\end{abstract}

\section{A. PENDAhuluan}

Dalam beberapa tahun terakhir, semakin banyak penelitian yang berfokus pada kinerja kreatif karyawan di tempat kerja (Liu et al., 2019; Martinaityte et al., 2019; Wallace et al., 2016). Hal ini dipacu oleh bukti kinerja kreatif sebagai faktor penting dalam menentukan kelangsungan hidup dan pengembangan perusahaan (Amabile, 1988; Saad et al., 2015). Kinerja inovasi perusahaan di Indonesia dapat dilihat dari kinerja proyek, kinerja pemasaran, keunggulan perusahaan, dan keunggulan bersaing (Aryanto et al., 2015; Hendrayati \& Gaffar, 2016; Julison et al., 2017). Di negara Cina, penekanan kinerja kreatif sangat penting bagi perusahaan karena 
mereka berjuang untuk menciptakan keunggulan kompetitif melalui kinerja kreatif tersebut di pasar dengan banyaknya produk (Elia et al., 2020; J. Hong et al., 2019). Penelitian yang dilakukan di sektor publik Norwegia oleh Mutonyi et al. (2020) mendapatkan data bahwa kinerja kreatif dipengaruhi oleh iklim organisasi.

Kinerja kreatif perusahaan terkait erat dengan karyawannya, dan mereka memainkan peran penting dalam kegiatan kreatif (Khalili, 2016). Kunci untuk mempromosikan kinerja kreatif perusahaan adalah meningkatkan kinerja kreatif karyawannya (Chen et al., 2015; Choi, 2007). Penelitian saat ini tentang kinerja kreatif karyawan telah menemukan bahwa banyak faktor mempengaruhi kinerja kreatif seseorang, seperti modal psikologis (Pieterse et al., 2010), berbagi pengetahuan (Carmeli et al., 2013; Sharifirad, 2016), iklim kreatif (Isaksen \& Ekvall, 2010), gaya kepemimpinan (Gilmore et al., 2013; Griffith et al., 2018; Shin \& Zhou, 2003), keterlibatan pekerjaan (Zhang \& Bartol, 2010), hadiah (Malik et al., 2015), dan kontrak psikologis (Ng et al., 2010). Faktor-faktor ini dapat dibagi menjadi dua kategori utama: perilaku dan psikologis. Tetapi semakin banyak peneliti menemukan bahwa faktor-faktor ini dipengaruhi oleh nilai-nilai kerja, dan penelitian telah menetapkan nilai-nilai kerja sebagai faktor antecedent yang mempengaruhi perilaku kerja dan sikap mental karyawan (Kirkman \& Shapiro, 2001; Williams et al., 2017). Nilai kerja mempengaruhi perilaku karyawan lalu menentukan kinerja mereka (Elizur \& Sagie,
1999; Froese \& Xiao, 2012; Ueda \& Ohzono, 2012), jadi kami mengusulkan bahwa nilai-nilai kerja mungkin memiliki efek penting pada perilaku kreatif dan kinerja kreatif karyawan.

Berbagi pengetahuan didefinisikan sebagai kegiatan yang terlibat dalam penyebaran atau transfer pengetahuan antara individu, kelompok atau organisasi (Lee, 2001; Tong, Tak, \& Wong, 2015). Berbagi pengetahuan memiliki dampak positif pada organisasi, karena dapat mempromosikan aliran pengetahuan, informasi dan keterampilan antara individu dan organisasi, dan meningkatkan tingkat kreatif organisasi dan individu (Charband \& Navimipour, 2018; Ma et al., 2017; Navimipour et al., 2015a; Navimipour et al., 2015b; Zareie \& Navimipour, 2016). Memang, berbagi pengetahuan didorong oleh tiga pendorong utama, yaitu orang, organisasi, dan teknologi informasi (Charband \& Navimipour, 2018; Fouladi \& Navimipour, 2017; Navimipour \& Charband, 2016), dan orang-orang adalah faktor penting. Dengan demikian, bagaimana mendorong perilaku berbagi pengetahuan karyawan adalah masalah penelitian yang penting. Meskipun beberapa peneliti mempelajari berbagi pengetahuan dari perspektif karyawan (Navimipour et al., 2015a; Navimipour et al., 2015b; Woodfield \& Husted, 2017), studi tentang mekanisme berbagi pengetahuan dari perspektif nilai-nilai kerja karyawan jarang terjadi dan karenanya penelitian yang relevan diperlukan.

Singkatnya, penelitian telah menemukan banyak faktor yang mempengaruhi kinerja 
kreatif, tetapi beberapa penelitian telah berfokus pada hubungan antara nilai-nilai kerja dan kinerja kreatif, terutama dari perspektif berbagi pengetahuan (Charband \& Navimipour, 2016; Khalili, 2016; Woodfield \& Husted, 2017). Untuk mengisi kesenjangan ini, penelitian ini menunjukkan hubungan antara keduanya melalui studi empiris, dan selanjutnya mengeksplorasi dampak nilai-nilai kerja dan berbagi pengetahuan pada kinerja kreatif.

\section{B. METODE}

Dalam penelitian ini kami memiliki populasi sebanyak 1.718 perwakilan perusahaan konstruksi (dengan jabatan minimal engineer) dari 1.718 perusahaan konstruksi (baik swasta maupun negeri) sebagai target penelitian. Penentuan sampel menggunakan pendekatan rumus Slovin (Tejada \& Punzalan, 2012) pada tingkat presisi $5 \%$ dalam perhitungan dan didapatkan sampel sebanyak 324 perwakilan perusahaan konstruksi yang akan dilibatkan dalam penelitian ini. Kami mengirimkan kuesioner ke 324 perwakilan perusahaan konstruksi melalui surel; dari jumlah tersebut, 315 responden mengirimkan kembali kuesioner mereka yang menghasilkan tingkat respons 97.22\%. Sebanyak 67 (21.3\%) responden adalah perempuan; 248 (78.7\%) laki-laki. Sebanyak 3 orang (1\%) berpengalaman 1-5 tahun, 7 orang (2.2\%) berpengalaman 6-10 tahun, dan 305 (97.1\%) berpengalaman 11-15 tahun kerja. Dari segi latar belakang pendidikan, 2 orang $(0.6 \%)$ memiliki gelar diploma, 312 orang (99\%) memiliki gelar sarjana, dan 1 orang (0.3\%) memiliki gelar master. Dari segi pekerjaan, 2 orang $(0.6 \%)$ sebagai engineer, 3 orang (1\%) sebagai project management team, 306 orang (97.1\%) sebagai leader, dan 4 orang (1.3\%) sebagai staf lainnya.

Kami mengukur nilai kerja dengan menggunakan skala 21 item yang dikembangkan oleh Meyer et al. (1998) $(\alpha=0,820)$. Skala ini mencakup tiga dimensi: kenyamanan, kompetensi, dan status. Dimensi kenyamanan diukur dengan skala lima item (misalnya "Mengizinkan rutinitas rutin dalam waktu dan tempat kerja"). Dimensi kompetensi berisi skala tujuh item (misalnya "Membutuhkan pertemuan dan berbicara dengan banyak orang lain"). Dimensi status diukur dengan skala sembilan item (misalnya "Kemajuan izin ke tanggung jawab administrasi yang tinggi"). Nilai $\alpha$ untuk ketiga jenis ini adalah 0.872, 0.903, dan 0.888. Item-item ini diukur pada skala tipe Likert lima nilai, mulai dari 1 "tidak penting" hingga 5 "sangat penting."

Kami menilai niat berbagi pengetahuan peserta menggunakan skala empat item yang dikembangkan oleh Pi et al. (2013). Contoh item adalah "Saya senang berbagi pengetahuan dan pengalaman dengan rekan saya." Koefisien $\alpha$ untuk skala ini adalah 0.900. Item-item ini diukur pada skala dari 1 "sangat tidak setuju" menjadi 5 "sangat setuju."

Atasan yang akrab dengan perilaku kerja bawahan diminta untuk menilai kinerja kreatif karyawan menggunakan skala empat item (Welbourne et al., 1998). Contohnya adalah 
"Menyediakan ide-ide baru untuk meningkatkan kondisi yang ada." Koefisien $\alpha$ untuk skala ini adalah 0.840 (Song et al., 2017). Item-item ini diukur pada skala lima poin dari 1 "tidak pernah terjadi" hingga 5 "sering."

Analisis statistik inferensial yang digunakan untuk menguji hipotesis penelitian sesuai dengan Gambar 1 adalah structural equation modelling partial least squares (SEM-PLS) menggunakan perangkat lunak SmartPLS 3.2.8. Signifikansi yang digunakan pada penelitian ini sebesar 0.05 dan digunakan uji one-tailed. Pendekatan kuantitatif digunakan dalam analisa data. Analisa statistika deskriptif untuk menentukan distribusi frekuensi jawaban dan kuesioner yang sudah diisi.

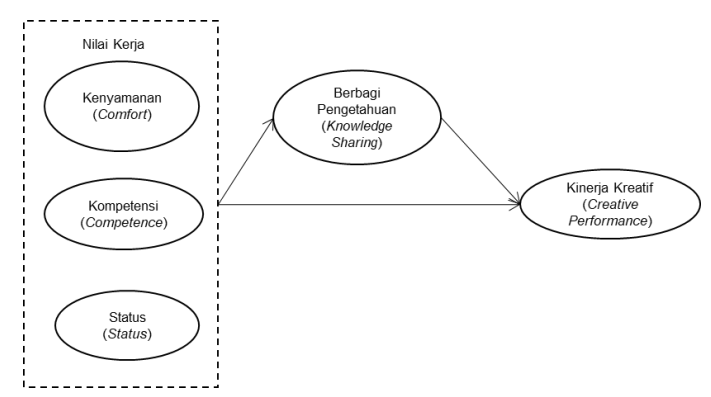

Gambar 1. Model Penelitian

\section{HASIL DAN PEMBAHASAN}

\section{Model Pengukuran}

Evaluasi model pengukuran (outer model) dilakukan untuk menentukan validitas dan keandalan yang menghubungkan indikator dengan variabel latennya. Ada tiga kriteria dalam menggunakan teknik analisis data dengan SmartPLS 3.2.8 untuk mengevaluasi outer model, yaitu convergent validity, discriminant validity, composite reliability, and average variance extracted (AVE) (Cepeda-Carrion et al., 2019; Hair et al., 2014).

Validitas konvergen pada model pengukuran dengan indikator reflektif dievaluasi berdasarkan korelasi antara skor pernyataan atau bagian yang diestimasi menggunakan perangkat lunak PLS. Pengukuran nilai reflektif dikatakan tinggi jika bernilai lebih dari 0,70 dari konstruk yang diukur (Hair et al., 2014). Dalam penelitian ini, batas nilai factor loading sebesar 0,70 akan digunakan. Berdasarkan analisa masih terdapat nilai factor loading dibawah 0,70 sehingga indikator tersebut harus dihapus atau dihilangkan. Indikator yang dihilangkan adalah Kompetensi2, Kompetensi4, dan BerbagiPengetahuan5. Hasil pemrosesan data untuk nilai faktor loading dibawah 0,70 yang sudah dihapus dapat dilihat pada Gambar 2.

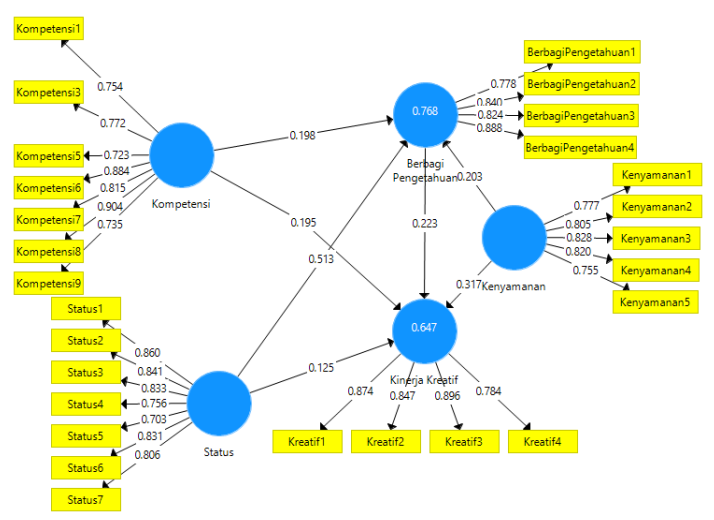

Gambar 2. Hasil Analisis Jalur

\section{Validitas Diskriminan}

Setelah memastikan bahwa semua indikator variabel laten adalah konstruksi variabel laten, langkah selanjutnya adalah menguji validitas diskriminan. Validitas diskriminan juga perlu dilakukan agar skala yang digunakan tidak terdiri dari dua konstruk yang mengukur hal yang sama. 
Untuk mengetahuinya, korelasi antara konstruk harus kurang dari 0,90. Jika antara konstruk, korelasinya adalah 0,90 atau lebih, multikolinearitas antara konstruksi akan terjadi (Hair et al., 2014). Hasil pengujian validitas diskriminan ditunjukkan dalam Tabel 1. Seperti yang ditunjukkan dalam Tabel 1, tidak ada multikoliniaritas antara variabel karena setiap konstruk mengukur hal-hal yang berbeda.

Tabel 1. Validitas Diskriminan

\begin{tabular}{|c|c|c|c|c|c|}
\hline & KEN & KOM & KRE & BP & ST \\
\hline KEN & 0,830 & & & & \\
\hline KOM & 0,798 & 0,801 & & & \\
\hline KRE & 0,748 & 0,769 & 0,851 & & \\
\hline BP & 0,769 & 0,834 & 0,742 & 0,857 & \\
\hline ST & 0,783 & 0,806 & 0,752 & 0,831 & 0,869 \\
\hline
\end{tabular}

Keterangan: $\mathrm{KEN}=$ Kenyamanan; $\mathrm{KOM}=$ Kompetensi; $\mathrm{KRE}=$ Kinerja Kreatif; $\mathrm{BP}=$ Berbagi Pengetahuan; $\mathrm{ST}=$ Status

\section{Reliabilitas}

Kriteria validitas dan keandalan juga dapat dilihat dari nilai keandalan konstruk dan nilai AVE dari setiap konstruk. Konstruk dikatakan memiliki keandalan tinggi jika nilainya 0,70 dan AVE di atas 0,50 (Hair et al., 2014). Indeks composite reliability dari setiap skala semuanya lebih besar dari level 0,70 yang direkomendasikan oleh Fornell \& Larcker (1981). Tabel 2 menyajikan nilai $\mathrm{C} \alpha$, composite reliability (CR), dan AVE untuk semua variabel.

Tabel 2. Konsistensi dan Reliabilitas

\begin{tabular}{|c|c|c|c|}
\hline Variabel & $\begin{array}{c}\text { Cronbach's } \\
\text { alpha }\end{array}$ & CR & AVE \\
\hline Kenyamanan & 0,858 & 0,897 & 0,636 \\
\hline Kompetensi & 0,906 & 0,926 & 0,641 \\
\hline
\end{tabular}

\begin{tabular}{|c|c|c|c|}
\hline Variabel & $\begin{array}{c}\text { Cronbach's } \\
\text { alpha }\end{array}$ & $\boldsymbol{C R}$ & AVE \\
\hline Status & 0,910 & 0,928 & 0,649 \\
\hline $\begin{array}{c}\text { Berbagi } \\
\text { Pengetahuan }\end{array}$ & 0,854 & 0,901 & 0,649 \\
\hline Kinerja Kreatif & 0,873 & 0,913 & 0,725 \\
\hline
\end{tabular}

Seperti yang ditunjukkan pada Tabel 2, Kenyamanan, Kompetensi, Status, Berbagi Pengetahuan, and Kinerja Kreatif memiliki CR di atas 0,80 dan nilai $C \alpha$ di atas 0,70 sehingga dapat disimpulkan bahwa indikator yang digunakan dalam setiap variabel memiliki keandalan yang baik atau dapat mengukur (Hair et al., 2014). Namun, nilai C $\alpha$ yang dihasilkan oleh PLS sedikit diremehkan sehingga disarankan untuk menggunakan nilai CR (Peterson \& Kim, 2013). Demikian juga dengan nilai AVE, variabel di atas memiliki nilai AVE di atas 0,50 sehingga dapat dikatakan bahwa setiap variabel memiliki validitas diskriminan yang tinggi.

\section{Model Struktural}

Pengujian inner model atau model struktural dilakukan untuk melihat hubungan antara konstruksi, nilai signifikansi, dan $\mathrm{R}^{2}$ dari model penelitian (Hair et al., 2019). Model struktural dievaluasi menggunakan $R^{2}$ untuk konstruk yang tergantung dari uji-t serta signifikansi koefisien parameter jalur struktural. Penilaian model dengan PLS dimulai dengan melihat $\mathrm{R}^{2}$ untuk setiap variabel dependen laten. Tabel 3 memperlihatkan hasil estimasi $R^{2}$ menggunakan SmartPLS versi 3.2.8. 
Tabel 3. Hasil R-Square

\begin{tabular}{|c|c|c|c|}
\hline Variabel & $\boldsymbol{R}^{\mathbf{2}}$ & $\begin{array}{c}\boldsymbol{R}^{\mathbf{2}} \\
\text { adjusted }\end{array}$ & $\boldsymbol{Q}^{\mathbf{2}}$ \\
\hline Kinerja Kreatif & 0.647 & 0.642 & 0,918104 \\
\hline $\begin{array}{c}\text { Berbagi } \\
\text { Pengetahuan }\end{array}$ & 0.768 & 0.766 & \\
\hline
\end{tabular}

Tabel 2 menunjukkan bahwa nilai $\mathrm{R}^{2}$ untuk kinerja kreatif sebesar 0,647 dan untuk berbagi pengetahuan sebesar 0,768. Hasil ini mengindikasikan bahwa sebesar $64,7 \%$ kinerja kreatif dipengaruhi oleh kenyamanan, kompetensi, status, dan berbagi pengetahuan; dimana sisanya dipengaruhi oleh variabel lainnya diluar penelitian ini. Kemudian, 76,8\% berbabgi pengetahuan dipengaruhi oleh kenyamanan, kompetensi, dan status; dimana sisanya dipengaruhi oleh variabel lainnya diluar penelitian ini.

Nilai prediktif relevansi $\left(Q^{2}\right)$ untuk model struktural pada penelitian ini sebesar 91,8\%. Maknanya adalah model penelitian dapat menjelaskan fenomena kinerja kreatif yang dihubungkan dengan beberapa variabel seperti kenyamanan, kompetensi, status, dan berbagi pengetahuan. Selanjutnya, model dapat dikatakan memiliki nilai prediktif yang baik dan dapat digunakan dalam penelitian. Pada akhirnya, model dapat digunakan untuk pengujian hipotesis.

\section{Uji Hipotesis}

Setelah mengetahui validitas dan keandalan item kuesioner dan mengetahui model yang dihasilkan dari analisis SEM dan kelayakan model, kami menguji hipotesis yang dikompilasi sebelumnya. Pengujian hipotesis ini didasarkan pada nilai signifikansi (nilai p) $<0,05$. Jika nilai signifikansi kurang dari 0,05, ada pengaruh antara variabel dan hipotesis yang diterima. Kami melakukan bootstrapping sebanyak 5.000 sub-sampel untuk mengukur $p$ value pada pengaruh langsung dan tidak langsung. Hasil pengujian hipotesis untuk efek langsung dan tidak langsung dapat dilihat pada Tabel 4 dan Tabel 5 di bawah ini.

Tabel 4. Efek Langsung

\begin{tabular}{|c|c|c|c|c|}
\hline Hipotesis & Hubungan & $\boldsymbol{\beta}$ & $\begin{array}{c}\boldsymbol{p} \\
\text { values }\end{array}$ & Keterangan \\
\hline $\mathrm{H} 1$ & KEN $\rightarrow$ KRE & 0,317 & 0,006 & $\begin{array}{c}\text { Tidak } \\
\text { signifikan }\end{array}$ \\
\hline $\mathrm{H} 2$ & $\begin{array}{c}\mathrm{KOM} \rightarrow \\
\mathrm{KRE}\end{array}$ & 0,195 & 0,153 & $\begin{array}{c}\text { Tidak } \\
\text { signifikan }\end{array}$ \\
\hline $\mathrm{H} 3$ & $\mathrm{ST} \rightarrow \mathrm{KRE}$ & 0,125 & 0,238 & $\begin{array}{c}\text { Tidak } \\
\text { signifikan }\end{array}$ \\
\hline $\mathrm{H} 4$ & $\mathrm{BP} \rightarrow \mathrm{KRE}$ & 0,223 & 0,005 & Signifikan \\
\hline
\end{tabular}
Keterangan: $\mathrm{KEN}=$ Kenyamanan; $\mathrm{KOM}=$ Kompetensi; $\mathrm{KRE}=$ Kinerja Kreatif; BP = Berbagi Pengetahuan; ST = Status

Pada efek tidak langsung, Tabel 5 menunjukkan terdapat dua hipotesis yang signifikan. Kami melakukan prosedur bootstrapping dengan pendekatan 5.000 subsampel untuk mengestimasi nilai $p$ pada tingkat signifikansi 0,05 untuk pengaruh tidak langsung sebagaimana pada Tabel 5.

Tabel 5. Efek Tidak Langsung

\begin{tabular}{|c|c|c|c|c|}
\hline Hipotesis & Hubungan & $\boldsymbol{\beta}$ & $\begin{array}{c}\boldsymbol{p} \\
\text { values }\end{array}$ & Keterangan \\
\hline H5a & $\begin{array}{c}\text { KEN } \rightarrow \text { BP } \\
\rightarrow \text { KRE }\end{array}$ & 0,045 & 0,029 & Signifikan \\
\hline H5b & $\begin{array}{c}\mathrm{KOM} \rightarrow \\
\mathrm{BP} \rightarrow \mathrm{KRE}\end{array}$ & 0,044 & 0,174 & $\begin{array}{c}\text { Tidak } \\
\text { signifikan }\end{array}$ \\
\hline H5c & $\begin{array}{c}\mathrm{ST} \rightarrow \mathrm{BP} \\
\rightarrow \mathrm{KRE}\end{array}$ & 0,114 & 0,028 & Signifikan \\
\hline
\end{tabular}

Keterangan: $\mathrm{KEN}=$ Kenyamanan; $\mathrm{KOM}=$ Kompetensi; $\mathrm{KRE}=$ Kinerja Kreatif; BP = Berbagi Pengetahuan; ST = Status 


\section{Pembahasan}

Pertama, penelitian ini telah menemukan faktor antecedent baru untuk kinerja kreatif. Di masa lalu, penelitian tentang mekanisme generasi kinerja kreatif terutama berfokus pada perilaku karyawan dan faktor organisasi (Carmeli et al., 2013; Wallace et al., 2016). Studi ini menemukan dampak nilai kerja terhadap kinerja kreatif melalui penelitian empiris. Temuan kami menunjukkan bahwa nilai kerja karyawan khususnya dimensi kenyamanan dan dimensi status memiliki dampak yang tidak signifikan pada kinerja kreatif jika tanpa dimediasi intensi berbagi pengetahuan. Penelitian menyimpulkan bahwa dengan diperantarai intensi berbagi pengetahuan, nilai-nilai kerja akan berpengaruh terhadap kreativitas. Kenyamanan memiliki dampak negatif yang tidak signifikan pada kinerja kreatif. Kompetensi dan status memiliki tidak mempengaruhi secara signifikan pada kinerja kreatif. Kesimpulan penelitian ini memiliki nilai teoritis dan signifikansi. Penelitian ini tidak hanya akan mengidentifikasi faktor-faktor baru yang mempengaruhi kinerja kreatif tetapi juga mempromosikan penelitian lebih lanjut yang dilakukan di bidang industri yang lain. Ini memberikan perspektif baru untuk penelitian di masa depan dan mempromosikan penelitian lebih lanjut tentang hubungan antara nilai-nilai kerja dan kinerja kreatif.

Kedua, penelitian ini mengeksplorasi mekanisme kinerja kreatif dari perspektif nilainilai kerja. Melalui penelitian ini, kami menemukan jalan pengaruh yang memiliki nilainilai kerja pada kinerja kreatif. Secara khusus, nilai kenyamanan dan status memiliki dampak tidak langsung pada kinerja kreatif. Pengaruh mereka dihasilkan oleh mediasi penuh berbagi pengetahuan. Sedangkan, nilai kompetensi tidak secara langsung mempengaruhi kinerja kreatif, dan tidak juga memiliki efek tidak langsung melalui mediasi berbagi pengetahuan. Penelitian ini tidak hanya memperkaya dan mengembangkan hasil penelitian yang ada tetapi juga menjelaskan jalur pengaruh nilai-nilai kerja pada kinerja kreatif.

\section{PENUTUP}

\section{Kesimpulan}

Singkatnya, makalah ini menemukan hubungan antara nilai-nilai kerja dan kinerja kreatif melalui studi empiris, melebarkan bidang penelitian nilai-nilai kerja dan dengan demikian mengisi kesenjangan dalam penelitian yang ada. Pada saat yang sama, penelitian ini juga menetapkan mekanisme spesifik pengaruh nilai kerja pada kinerja kreatif dengan mediasi berbagi pengetahuan. Kesimpulan yang dihasilkan mempromosikan pengembangan teori kreatif.

Temuan ini juga memberikan panduan penting dan memiliki nilai referensi untuk praktik manajemen. Kinerja kreatif adalah jaminan penting bagi perusahaan untuk mendapatkan keunggulan kompetitif, dan memiliki arti khusus bagi perusahaan dalam lingkungan persaingan pasar yang sengit. Hubungan antara nilai kerja 
dan kinerja kreatif, serta mekanisme pengaruh, memberikan ide manajemen penting bagi manajer untuk secara efektif meningkatkan kinerja kreatif karyawan. Temuan ini memungkinkan manajer untuk melihat pentingnya nilai kerja untuk kinerja inovasi. Ini dapat menginspirasi manajer untuk mengambil langkah-langkah yang ditargetkan dalam pekerjaan mereka untuk meningkatkan tingkat kinerja kreatif.

\section{Saran}

Makalah ini mengusulkan dua saran untuk praktik manajemen. Pertama, memperhatikan pengelolaan nilai-nilai kerja karyawan. Menurut teori verifikasi diri dan hasil penelitian nilai-nilai kerja, kita dapat mengetahui bahwa nilai-nilai intrinsik karyawan akan berdampak penting pada sikap dan perilaku kerja mereka (Blickle et al., 2011; Jalalkamali, Ali, Hyun, \& Nikbin, 2016; Swann, 1990). Oleh karena itu, manajer harus lebih memperhatikan pengelolaan nilai-nilai kerja karyawan dan menetapkan mekanisme evaluasi dan seleksi ilmiah khususnya menerapkan manajemen pengetahuan dalam implementasinya. Khusus untuk posisi dengan persyaratan kreatif yang tinggi, manajer harus mengadopsi alat evaluasi nilai ilmiah dan efektif untuk memilih karyawan yang mengejar kemampuan dan pertumbuhan, status, dan kemandirian yang lebih tinggi. Kedua, membangun mekanisme berbagi pengetahuan di perusahaan. Teori inovasi dan hasil penelitian terkait menunjukkan bahwa berbagi pengetahuan memainkan peran yang sangat positif dalam mempromosikan kinerja inovasi karyawan (P. Hong, Doll, Nahm, \& li, 2004; Sharifirad, 2016; Tong et al., 2015). Manajer harus memperhatikan pembangunan mekanisme berbagi pengetahuan, menerobos pemikiran dan mode tradisional, memanfaatkan sepenuhnya alat modern untuk membangun platform berbagi pengetahuan, memperluas saluran berbagi pengetahuan, meningkatkan kenyamanan, dan meninjau efektivitas berbagi pengetahuan.

Penelitian ini memiliki dua keterbatasan utama. Salah satunya adalah masalah validitas eksternal. Data penelitian dikumpulkan hanya dari 315 perusahaan konstruksi di Jakarta yang diwakili oleh perwakilan perusahaan sebagai sampel. Sesuai dengan pendekatan Slovin, sampel yang harus didapatkan sebanyak 324 responden, namun hanya 315 responden saja yang merespon. Masalah lainnya adalah bahwa penelitian ini mengabaikan dampak faktor tingkat organisasi. Nilai-nilai kerja dapat dipengaruhi oleh faktor organisasi, seperti kepemimpinan atau budaya perusahaan. Dengan demikian, studi di masa depan harus lebih memperhatikan efek dari faktor-faktor ini pada hubungan antara nilai-nilai kerja dan kinerja kreatif.

\section{DAFTAR PUSTAKA}

Amabile, T. (1988). A model of creativity and innovation in organizations. Research in Organizational Behavior, 10(1), 123-167.

Aryanto, R., Fontana, A., \& Afiff, A. Z. (2015). 
Strategic Human Resource Management, Innovation Capability and Performance: An Empirical Study in Indonesia Software Industry. Procedia - Social and Behavioral Sciences, 211(September), 874-879. https://doi.org/10.1016/j.sbspro.2015.11. 115

Blickle, G., Fröhlich, J. K., Ehlert, S., Pirner, K., Dietl, E., Hanes, T. J., \& Ferris, G. R. (2011). Socioanalytic theory and work behavior: Roles of work values and political skill in job performance and promotability assessment. Journal of Vocational Behavior, 78(1), 136-148. https://doi.org/10.1016/j.jvb.2010.05.010

Carmeli, A., Gelbard, R., \& Reiter-Palmon, R. (2013). Leadership, Creative ProblemSolving Capacity, and Creative Performance: The Importance of Knowledge Sharing. Human Resource Management, 52(1), 95-121. https://doi.org/10.1002/hrm

Cepeda-Carrion, G., Cegarra-Navarro, J. G., \& Cillo, V. (2019). Tips to use partial least squares structural equation modelling (PLS-SEM) in knowledge management. Journal of Knowledge Management, 23(1), 67-89. https://doi.org/10.1108/JKM-052018-0322

Charband, Y., \& Jafari Navimipour, N. (2016). Online knowledge sharing mechanisms: a systematic review of the state of the art literature and recommendations for future research. Information Systems Frontiers, 18(6) 1131-1151. https://doi.org/10.1007/s10796-0169628-z

Charband, Y., \& Navimipour, N. J. (2018). Knowledge sharing mechanisms in the education: A systematic review of the state of the art literature and recommendations for future research. Kybernetes, 47(7), 1456-1490. https://doi.org/10.1108/K-062017-0227

Chen, M. H., Chang, Y. Y., \& Chang, Y. C. (2015). Entrepreneurial Orientation, Social Networks, and Creative Performance: Middle Managers as Corporate Entrepreneurs. Creativity and Innovation
Management, 24(3), 493-507. https://doi.org/10.1111/caim.12108

Choi, J. N. (2007). Group composition and employee creative behaviour in a Korean electronics company: Distinct effects of relational demography and group diversity. Journal of Occupational and Organizational Psychology, 80(2), 213-234. https://doi.org/10.1348/096317906X1102 50

Elia, S., Kafouros, M., \& Buckley, P. J. (2020). The role of internationalization in enhancing the innovation performance of Chinese EMNEs: A geographic relational approach. Journal of International Management, 26(4), 100801. https://doi.org/10.1016/j.intman.2020.10 0801

Elizur, D., \& Sagie, A. (1999). Facets of personal values: A structural analysis of life and work values. Applied Psychology, 48(1), 73-87. https://doi.org/10.1080/02699949937767 3

Fornell, C., \& Larcker, D. F. (1981). Structural Equation Models with Unobservable Variables and Measurement Error: Algebra and Statistics. Journal of Marketing Research, $\quad 382$. https://doi.org/10.2307/3150980

Fouladi, P., \& Navimipour, N. J. (2017). Human resources ranking in a cloud-based knowledge sharing framework using the quality control criteria. Kybernetes, 46(5), 876-892. https://doi.org/10.1108/K-012017-0007

Froese, F. J., \& Xiao, S. (2012). Work values, job satisfaction, and organizational commitment in China. International Journal of Human Resource Management, 23(10), 2144-2162. https://doi.org/10.1080/09585192.2011.6 10342

Gilmore, P. L., Hu, X., Wei, F., Tetrick, L. E., \& Zaccaro, S. J. (2013). Positive affectivity neutralizes transformational leadership's influence on creative performance and organizational citizenship behaviors. Journal of Marriage and Family, 34(8), 
1061-1075.

https://doi.org/10.1002/job.1833

Griffith, J. A., Gibson, C., Medeiros, K., MacDougall, A., Hardy, J., \& Mumford, M. D. (2018). Are You Thinking What I'm Thinking?: The Influence of Leader Style, Distance, and Leader-Follower Mental Model Congruence on Creative Performance. Journal of Leadership and Organizational Studies, 25(2), 153-170. https://doi.org/10.1177/15480518177505 37

Hair, Joe F., Sarstedt, M., Hopkins, L., \& Kuppelwieser, V. G. (2014). Partial least squares structural equation modeling (PLSSEM): An emerging tool in business research. European Business Review, 26(2), 106-121. https://doi.org/10.1108/EBR-102013-0128

Hair, Joseph F., Sarstedt, M., \& Ringle, C. M. (2019). Rethinking some of the rethinking of partial least squares. European Journal of Marketing, 53(4), 566-584. https://doi.org/10.1108/EJM-10-20180665

Hendrayati, H., \& Gaffar, V. (2016). Innovation and Marketing Performance of Womenpreneur in Fashion Industry in Indonesia. Procedia - Social and Behavioral Sciences, 219, 299-306. https://doi.org/10.1016/j.sbspro.2016.04. 034

Hong, J., Zheng, R., Deng, H., \& Zhou, Y. (2019). Green supply chain collaborative innovation, absorptive capacity and innovation performance: Evidence from China. Journal of Cleaner Production, 241, 118377.

https://doi.org/10.1016/j.jclepro.2019.11 8377

Hong, P., Doll, W. J., Nahm, A. Y., \& li, X. (2004). Knowledge sharing in integrated product development. European Journal of Innovation Management, 7(2), 102-112. https://doi.org/10.1108/14601060410534 393

Isaksen, S. G., \& Ekvall, G. (2010). Managing for innovation: The two faces of tension in creative climates. Creativity and Innovation

Management, 19(2), 73-88. https://doi.org/10.1111/j.1467-

8691.2010.00558.x

Jalalkamali, M., Ali, A. J., Hyun, S. S., \& Nikbin, D. (2016). Relationships between work values, communication satisfaction, and employee job performance: The case of international joint ventures in Iran. Management Decision, 54(4), 796-814. https://doi.org/10.1108/MD-01-20150003

Julison, B., Wardani, S. P. R., \& Wibowo, M. A. (2017). Innovation Performance of Large Contractor in Indonesia: Influencing Factors and its Impact on Firm's Performance. Procedia Engineering, 171, 370-378.

https://doi.org/10.1016/j.proeng.2017.01. 346

Khalili, A. (2016). Linking leaders' emotional intelligence competencies and employees' creative performance and innovative behaviour: Evidence from different nations. International Journal of Innovation Management, 20(7), 1650069. https://doi.org/10.1142/S1363919616500 699

Kirkman, B. L., \& Shapiro, D. L. (2001). The Impact of Cultural Values on Job Satisfaction and Organizational Commitment in Self-Managing Work Teams: The Mediating Role of Employee Resistance. Academy of Management, 44(3), 557-569.

Lee, J. N. (2001). The impact of knowledge sharing, organizational capability and partnership quality on IS outsourcing success. Information and Management, 38(5), 323-335. https://doi.org/10.1016/S03787206(00)00074-4

Liu, Y., Wang, S., \& Yao, X. (2019). Individual Goal Orientations, Team Empowerment, and Employee Creative Performance: A Case of Cross-level Interactions. Journal of Creative Behavior, 53(4), 443-456. https://doi.org/10.1002/jocb.220 
Ma, Z., Long, L., Zhang, Y., Zhang, J., \& Lam, C. K. (2017). Why do high-performance human resource practices matter for team creativity? The mediating role of collective efficacy and knowledge sharing. Asia Pacific Journal of Management, 34(3), 565586. https://doi.org/10.1007/s10490-0179508-1

Malik, M. A. R., Butt, A. N., \& Choi, J. N. (2015). Rewards and employee creative performance: Moderating effects of creative self-efficacy, reward importance, and locus of control. Journal of Organizational Behaviour, 36(1), 59-74. https://doi.org/10.1002/job.1943

Martinaityte, I., Sacramento, C., \& Aryee, S. (2019). Delighting the Customer: Creativity-Oriented High-Performance Work Systems, Frontline Employee Creative Performance, and Customer Satisfaction. Journal of Management, 45(2), 728-751. https://doi.org/10.1177/01492063166725 32

Meyer, J. P., Irving, P. G., \& Allen, N. J. (1998). Examination of the combined effects of work values and early work experiences on organizational commitment. Journal of Organizational Behavior, 19(1), 29-52.

Mutonyi, B. R., Slåtten, T., \& Lien, G. (2020). Organizational climate and creative performance in the public sector. European Business Review, 32(4), 615-631. https://doi.org/10.1108/EBR-02-20190021

Navimipour, N. J., \& Charband, Y. (2016). Knowledge sharing mechanisms and techniques in project teams: Literature review, classification, and current trends. Computers in Human Behavior, 62, 730742.

https://doi.org/10.1016/j.chb.2016.05.003

Navimipour, N. J., Navin, A. H., Rahmani, A. M., \& Hosseinzadeh, M. (2015). Behavioral modeling and automated verification of a Cloud-based framework to share the knowledge and skills of human resources. Computers in Industry, 68, 65-77. https://doi.org/10.1016/j.compind.2014.1
2.007

Navimipour, N. J., Rahmani, A. M., Navin, A. H., \& Hosseinzadeh, M. (2015). Expert Cloud: A Cloud-based framework to share the knowledge and skills of human resources. Computers in Human Behavior, 46, 57-74. https://doi.org/10.1016/j.chb.2015.01.001

Ng, T. W. H., Feldman, D. C., \& Lam, S. S. K. (2010). Psychological contract breaches, organizational commitment, and innovation-related behaviors: A latent growth modeling approach. Journal of Applied Psychology, 95(4), 744-751. https://doi.org/10.1037/a0018804

Peterson, R. A., \& Kim, Y. (2013). On the relationship between coefficient alpha and composite reliability. Journal of Applied Psychology, 98(1), 194-198. https://doi.org/10.1037/a0030767

Pi, S. M., Chou, C. H., \& Liao, H. L. (2013). A study of Facebook Groups members' knowledge sharing. Computers in Human Behavior, 29(5), 1971-1979. https://doi.org/10.1016/j.chb.2013.04.019

Pieterse, A. N., Knippenberg, D. V., Schippers, M., \& Stam, D. (2010). Transformational and transactional leadership and innovative behavior: The moderating role of psychological empowerement. Journal of Organizational Behavior, 31(4), 609623. https://doi.org/10.1002/job.650

Saad, G., Cleveland, M., \& Ho, L. (2015). Individualism-collectivism and the quantity versus quality dimensions of individual and group creative performance. Journal of Business Research, 68(3), 578-586. https://doi.org/10.1016/j.jbusres.2014.09. 004

Sharifirad, M. S. (2016). Can incivility impair team's creative performance through paralyzing employee's knowledge sharing? A multi-level approach. Leadership and Organization Development Journal, 37(2), 200-225. https://doi.org/10.1108/LODJ05-2014-0092

Shin, S. J., \& Zhou, J. (2003). Transformational Leadership, Conservation, and Creativity: Evidence From Korea. Academy of 
Management Journal, 46(6), 703-714. https://doi.org/10.5465/30040662

Song, J., Wu, J., \& Gu, J. (2017). Voice behavior and creative performance moderated by stressors. Journal of Managerial Psychology, 32(2), 177-192. https://doi.org/10.1108/JMP-03-20160078

Swann, W. B. (1990). To be adored or to be known? The interplay of self-enhancement and self-verification. In Motivation and Cognition (pp. 408-448).

Tejada, J., \& Punzalan, J. (2012). On the misuse of Slovin's formula. The Philippine Statistician, 61(1), 129-136.

Tong, C., Tak, W. I. W., \& Wong, A. (2015). The Impact of Knowledge Sharing on the Relationship between Organizational Culture and Job Satisfaction: the Perception of Information Communication and Technology (ICT) Practitioners in Hong Kong. International Journal of Human Resource Studies, 5(1), 19-47. https://doi.org/10.5296/ijhrs.v3i1.3112

Ueda, Y., \& Ohzono, Y. (2012). Effect of Work Values on Work Outcomes: Investigating Differences between Job Categories. International Journal of Business Administration, 3(2), 98-111. https://doi.org/10.5430/ijba.v3n2p98

Wallace, J. C., Butts, M. M., Johnson, P. D., Stevens, F. G., \& Smith, M. B. (2016). A Multilevel Model of Employee Innovation: Understanding the Effects of Regulatory Focus, Thriving, and Employee

\author{
Involvement Climate. Journal of \\ Management, 42(4), 982-1004. \\ https://doi.org/10.1177/01492063135064 \\ 62
}

Welbourne, T. M., Johnson, D. E., \& Erez, A. (1998). The role-based performance scale: Validity analysis of a theory-based measure. Academy of Management Journal, 41(5), 540-555. https://doi.org/10.2307/256941

Williams, P., Kern, M. L., \& Waters, L. (2017). The role and reprocessing of attitudes in fostering employee work happiness: An intervention study. Frontiers in Psychology, $8(28)$, 1-12. https://doi.org/10.3389/fpsyg.2017.00028

Woodfield, P., \& Husted, K. (2017). Intergenerational knowledge sharing in family firms: Case-based evidence from the New Zealand wine industry. Journal of Family Business Strategy, 8(1), 57-69. https://doi.org/10.1016/j.jfbs.2017.01.001

Zareie, B., \& Navimipour, N. J. (2016). The impact of electronic environmental knowledge on the environmental behaviors of people. Computers in Human Behavior, 59, 1-8. https://doi.org/10.1016/j.chb.2016.01.025

Zhang, X., \& Bartol, K. M. (2010). The influence of creative process engagement on employee creative performance and overall job performance: A curvilinear assessment. Journal of Applied Psychology, 95(5), 862-873. https://doi.org/10.1037/a0020173 